\title{
ECOLOGICAL ROLES OF NATURAL PRODUCTS OF THE BRAZILIAN RED SEAWEED Laurencia obtusa
}

\author{
PEREIRA, R. C., ${ }^{1}$ DA GAMA, B. A. P., ${ }^{1,2}$ TEIXEIRA, V. L. ${ }^{1}$ and \\ YONESHIGUE-VALENTIN, Y. ${ }^{2}$ \\ ${ }^{1}$ Departamento de Biologia Marinha, Universidade Federal Fluminense, \\ C.P. 100.644, CEP 24001-970, Niterói, RJ, Brazil \\ ${ }^{2}$ Pós-graduação em Biotecnologia Vegetal, Centro de Ciências da Saúde, Universidade Federal do Rio de Janeiro, \\ Ilha do Fundão, CEP 21949-900, Rio de Janeiro, RJ, Brazil \\ Correspondence to: Renato C. Pereira, Departamento de Biologia Marinha, Instituto de Biologia, Universidade \\ Federal Fluminense, C.P. 100.644, CEP 24001-970, Niterói, Rio de Janeiro, Brazil, e-mail: egbrecp@ vm.uff.br \\ Received September 9, 2002 - Accepted December 19, 2002 - Distributed November 30, 2003
}

(With 5 figures)

\begin{abstract}
Laboratory and field experiments were performed to assess the ecological roles of natural products produced by the Brazilian red seaweed Laurencia obtusa. Laboratory assays revealed that the natural concentration of the crude organic extract of $L$. obtusa significantly inhibited feeding by two herbivores: the crab Pachygrapsus transversus and the sea urchin Lytechinus variegatus. It was verified that this chemically defensive action was due to halogenated sesquiterpenoid elatol, found to be the major natural product of this red seaweed. In addition, it was verified that the antifouling property of the chemicals produced by $L$. obtusa could make this red alga less attractive for fish grazing. Direct protection against two herbivore species and indirect protection against herbivory by fouling inibition constitute evidence that the major natural product from Brazilian L. obtusa plays multiple environmental roles, thereby increasing the adaptive value of these metabolites. On the other hand, the evidence reinforces the idea that marine natural products may have different functions in the sea.
\end{abstract}

Key words: natural products, Laurencia obtusa, chemical defense, herbivory, fouling.

\section{RESUMO}

\section{Funções ecológicas de produtos naturais da alga vermelha brasileira Laurencia obtusa}

Foram realizadas experiências em laboratório e em campo, com o intuito de verificar as funções ecológicas de produtos naturais produzidos pela macroalga bentônica Laurencia obtusa da costa brasileira. Nas experiências em laboratório, foi constatado que a concentração natural do extrato orgânico bruto de $L$. obtusa inibiu significativamente seu consumo por dois herbívoros, o caranguejo Pachygrapsus transversus e o ouriço-do-mar Lytechinus variegatus. Foi verificado que essa ação defensiva deve-se ao elatol, um sesquiterpeno halogenado encontrado como o produto natural mais abundante nessa alga vermelha. Além disso, verificou-se que a propriedade antiincrustante desse metabólito produzido por L. obtusa poderia torná-la menos atrativa à herbivoria por peixes. A ação protetora direta contra duas espécies de herbívoros e uma proteção indireta contra a herbivoria por inibição da incrustação constituem evidências de que o produto natural majoritário encontrado em $L$. obtusa do Brasil possui múltiplas funções ecológicas no ambiente. Por outro lado, reforça a idéia de que produtos naturais marinhos podem ter diferentes funções no mar, aumentando, assim, o valor adaptativo desses metabólitos.

Palavras-chave: produtos naturais, Laurencia obtusa, defesa química, herbivoria, incrustação. 


\section{INTRODUCTION}

To date, over 2400 natural products have been isolated from seaweeds (mainly from the divisions Rhodophyta, Phaeophyta, and Chlorophyta), the majority of which come from subtropical and tropical populations (Munro \& Blunt, 1999; Faulkner, 2001, and previous reviews of this author). In general, lipophilic nonpolar compounds such as terpenoids, acetogenins, and compounds of mixed biosynthesis occur in relatively low concentrations (ranging from $0.2 \%$ to $2 \%$ of algal dry weight) but polar polyphenolics can occur in concentrations as high as $15 \%$ of algal dry mass (Hay \& Steinberg, 1992; Ragan \& Glombitza, 1986; Pereira \& Yoneshigue-Valentin, 1999).

The greatest variety of natural products is probably found among Rhodophyta, in which all known classes of compounds are represented, many of which are halogenated (Fenical, 1975; Faulkner, 2001, and previous reviews of this author). As an example of Rhodophyta's broad chemical variety, members of the genus Laurencia produce an amazing array of complex terpenoids and acetogenins, possibly making it the world's most chemically complex genus.

Among the Chlorophyta, the order Caulerpales has been especially well studied and calcified species of the genus Halimeda provide one of the most thoroughly studied examples of seaweed producing chemicals able to inhibit herbivory by reef fishes or exhibiting other biological activities (Paul \& Fenical, 1986, 1987). In fact, the ability of Halimeda species to persist in areas of intense herbivory pressure (e.g., coral reefs) results from the production of chemical defenses (Paul \& Van Alstyne, 1988).

In the Phaeophyta, Dictyota species have been extensively studied and are known to produce interesting natural products, many of which are broad-spectrum feeding deterrents against herbivores or show other biological activities (Hay \& Steinberg, 1992). For example, the diterpenes pachydictyol A, dictyol $\mathrm{E}$, dictyol B, dictyol $\mathrm{B}$ acetate, dictyol $\mathrm{H}$, (6R)-hydroxydichotoma-3,14-diene-1,17-dial, and an isolinerol/linearol mixture have been shown to be active anti-feedant metabolites (Hay \& Steinberg, 1992; Pereira et al., 1994, 2000, 2002).

Recent research in marine chemical ecology has clearly shown that many seaweed natural products that function as feeding deterrents may also play other roles, i.e., carry out multiple functions, acting simultaneously as feeding deterrents and defenses against pathogens and fouling organisms (Paul, 1992; Schmitt et al., 1995; McClintock \& Baker, 2001), thereby increasing the adaptive value of these metabolites (Paul, 1992). A consideration of the multiple functions of marine natural products is important since these compounds may have evolved for reasons other than defense against herbivores, such as resistance to pathogens, competitors, and others. Species of the genus Laurencia are known to produce a wide array of natural products exhibiting several kinds of biological activities (e.g., König et al., 2000; Pereira \& Teixeira, 1999) such as chemical defense against diverse marine herbivores: reef fish (Hay et al., 1987, 1988; Paul et al., 1988), the sea urchin Diadema (Hay et al., 1987), and the snail species Littorina strata and Osilinus atratus (Granado \& Caballero, 1995). Both sesquiterpene compounds, elatol and deschloroelatol, from the Australian seaweed Laurencia rigida produce very strong effects against invertebrate larvae and are thought to be highly toxic (de Nys et al., 1996). Recently, crude extracts and the major compound elatol found in the Brazilian alga $L$. obtusa have shown a specific antifouling activity against attachment of the mussel Perna perna in laboratory assays (da Gama et al., 2003), and a broad spectrum antifouling property in the field (da Gama et al., 2002).

The goal of this investigation was to evaluate the ecological roles of natural products produced by Brazilian specimens of the red alga Laurencia obtusa. We addressed the following questions: 1) do the crude extract and major pure compound produced by Brazilian Laurencia obtusa inhibit herbivory?; 2) by inhibiting the growth of epibionts, do these chemicals make this algal species less attractive to grazing by fish?

\section{MATERIALS AND METHODS}

\section{Algal collection}

Laurencia obtusa (Hudson) Lamouroux is an intertidal alga found along almost the whole Brazilian littoral (Oliveira Filho, 1977), and is especially common in shallow wave-washed areas with strong currents. Specimens of this red seaweed were collected by hand during low tide at Cabo Frio Island, Rio de Janeiro State, a region on the Brazilian southeastern coast.

\section{Chemical procedures}

After determining the fresh seaweed volume by water displacement into a graduated cylinder, the collected specimens of L. obtusa were air dried in the dark at room temperature (in order to avoid 
photolysis and thermal degradation of the metabolites) until a steady dry weight was obtained. Specimens of $L$. obtusa were then submitted to successive and exhaustive extraction in a combination of organic solvents (dichloromethane and methanol) in the proportion of 2:1, following standard procedures for natural products chemistry. To increase the effectiveness of extraction, dried seaweeds were submitted to ultrasound for 15 minutes (Branson model 3210). The combination of solvents was eliminated in vacuo and the remainder was weighed to determine the natural (both volumetric and dry weight) concentration of crude extract and major pure compound produced by L. obtusa.

In order to detect the presence of natural products on the seaweed surface, fresh specimens of L. obtusa were extracted in hexane during 40 seconds, a time period insufficient to allow cell lysis (de Nys et al., 1998). The surface extract was then compared by thinlayer chromatography (TLC) with the whole plant crude extract used in laboratory (herbivory tests) and field (antifouling tests) experiments.

\section{Effect of extract and pure major compound from L. obtusa on herbivore feeding}

The defensive properties of the crude extract and the major compound elatol, found in L. obtusa, against the crab Pachygrapsus transversus and the sea urchin Lytechinus variegatus were verified by including natural concentrations of both components in an artificial food (Hay et al., 1994; Pereira et al., 2000). This food (control) was prepared by adding $0.72 \mathrm{~g}$ of agar to $20.0 \mathrm{ml}$ of distilled water and heating it in a microwave oven until the boiling point. This mixture was added to $16.0 \mathrm{ml}$ of cold water containing $2.0 \mathrm{~g}$ of the freeze-dried green seaweed Ulva spp. The experimental food (treatment) was similarly prepared, but the crude extract or pure compound was first dissolved in diethyl ether, added to $2.0 \mathrm{~g}$ of freeze-dried Ulva, and the solvent was then removed by rotary evaporation. This procedure is necessary to obtain a uniform coating of natural products on the algal particles prior to their addition to the agar (Hay et al., 1994). Treatments and controls were hardened onto a screen and cut into small pieces ( $7 \times 10$ squares about $1.2 \times 1.4 \mathrm{~mm}$ each), which were then simultaneously offered to the crab $P$. transversus and the sea urchin $L$. variegatus. Crab assays were carried out in small plastic containers, each containing $250 \mathrm{ml}$ of seawater $(\mathrm{n}=21$ to 26 replicates; see "Results"), a small rock (as crabs usually hide under rocks), and 1 individual of $P$. transversus. The sea urchin assays were carried out in perforated plastic containers (1 1 seawater) holding 1 individual of $L$. variegatus ( $\mathrm{n}=18$ to 24 replicates; see "Results"), and placed in large tanks containing about $500 \mathrm{~L}$ of recirculating seawater.

For all assays, the defensive activities of the crude extract or pure compound were estimated by comparing the number of squares consumed between experimental foods (control and treatment). New crab and sea urchin specimens were used in each assay.

\section{Field fouling experiments}

Field fouling assays were carried out according to the method first devised by Henrikson \& Pawlik (1995) and fully described in da Gama et al. (2002). Experimental plates containing a natural concentration of $L$. obtusa extract and control plates were made of phytagel $^{\mathrm{TM}}$ (Sigma Chemical Co.) and immersed (1 m depth) for 7 weeks off Cabo Frio Island (Arraial do Cabo, State of Rio de Janeiro). Settlement of fouling in the field was measured weekly as percentcover, using a dot-grid method (Foster et al., 1991). The potential influence of chemicals in making $L$. obtusa less attractive to fish grazing was inferred by evaluation of total fouling cover $(\%)$ on gels and the scar cover (fish produced a clearly defined teeth scar on gels where there was fouling cover) produced by predatory fish $\left(\mathrm{as} \mathrm{mm}^{2}\right)$. Both observations were made after 5 weeks of immersion of the experimental plates (when fish grazing started).

\section{Statistical analyses}

The Wilcoxon matched pairs test, a nonparametric equivalent to the $t$-test, was used to evaluate the statistical significance of the results obtained in the feeding assays. Monofactorial analysis of variance (ANOVA) and post hoc Tukey's honest significant difference (HSD) test were used to check for differences among fouling and predation scars cover.

\section{RESULTS}

\section{Chemical procedures}

One purified fraction of the crude extract obtained from L. obtusa (corresponding to $4.07 \%$ of tissue dry weight, $\mathrm{dw}$ ), after application to a preparative thin layer chromatography plate, yielded a clear oil $(\mathrm{Rf}=0.66$, when eluted with $\mathrm{CH}_{2} \mathrm{Cl}_{2}$ ), corresponding to $11.06 \%$ of the crude extract and $0.45 \%$ of algal dry mass. This oil, the major compound present in the crude extract, 
was identified as the sesquiterpene alcohol elatol (Fig. 1) by comparison of physical and spectroscopic data $\left({ }^{13} \mathrm{C}\right.$ and ${ }^{1} \mathrm{H}-\mathrm{NMR}$, da Gama, 2001) with data reported in the literature (König \& Wright, 1997). This compound has also been found in other Laurencia species worldwide (Pereira, 1995).

The comparison by thin layer chromatography (TLC) between the surface extract and the whole plant extract used in laboratory (herbivory tests) and field (antifouling tests) revealed that the sesquiterpene elatol was also present at the algal surface, where it could in fact play a role as a defense against epibiosis.

\section{Herbivory responses to L. obtusa crude extract and elatol}

The $L$. obtusa crude extract was very effective ( $\mathrm{p}<0.05$, Wilcoxon test) as a chemical defense against herbivores in all laboratory trials, inhibiting feeding by the crab $P$. transversus and the sea urchin L. variegatus relative to controls (Figs. 2 and 3, respectively). This defensive property is clearly due to the major compound elatol found in this red seaweed, which also significantly reduced feeding by both herbivores, $P$. transversus and the sea urchin L. variegatus (Figs. 2 and 3, respectively). Thus, the chemically deterrent property of Brazilian $L$. obtusa is in reality due to the presence of elatol.

\section{Fouling consumption by predatory fish}

After 5 weeks of immersion of the experimental plates in the sea, it was verified that the crude extract from $L$. obtusa still exhibited a significant antifouling activity as compared to control plates (Fig. 4). In addition, fish consumption significantly reduced fouling cover in control plates as compared to plates containing the crude extract of L. obtusa (Fig. 5). Thus, chemicals found in L. obtusa inhibit fouling directly and, indirectly, consumption by predatory fish. Based on a comparison between the scars on gels and the mouth parts of collected fish, the fish predating on gels were identified as Kyphosus sectatrix (family Kyphosidae), an omnivorous fish commonly found on coastal areas, and known to graze even on chemically defended seaweeds (Targett \& Arnold, 2001).

\section{DISCUSSION}

In this study, it was found that the crude extract from Brazilian L. obtusa is an effective chemical defense against herbivory by the crab $P$. transversus and the sea urchin L. variegatus. In addition, it was discovered that this defensive property was due to the sesquiterpene compound elatol. As found in $L$. obtusa specimens from the Caribbean (Norris \& Fenical, 1982), elatol was determined to be the major natural product in populations of L. obtusa from the Brazilian coast. Elatol is a chamigrane-class sesquiterpenoid that was first isolated from specimens of Laurencia elata from Australia (Sims et al., 1974), and today is known as a common compound found in several other species of Laurencia worldwide (Pereira, 1995). In fact, Laurencia species have been extensively studied by chemists (Munro \& Blunt, 1999; Faulkner, 2001, and previous reviews of this author) and are known to produce a diverse array of natural products including halogenated terpenoid compounds with potential ecological properties (König \& Wright, 1997).

Previous research has demonstrated that elatol is broadly effective as a feeding deterrent against reef fish in the field (Hay et al., 1987, 1988; Paul et al., 1988), the sea urchin Diadema (Hay et al., 1987), and two snail species, Littorina strata and Osilinus atratus (Granado \& Caballero, 1995). Our results widen the action spectrum of elatol as a chemical defense against a variety of common marine herbivores, while also suggesting that this compound is responsible for inhibiting fouling in the field.

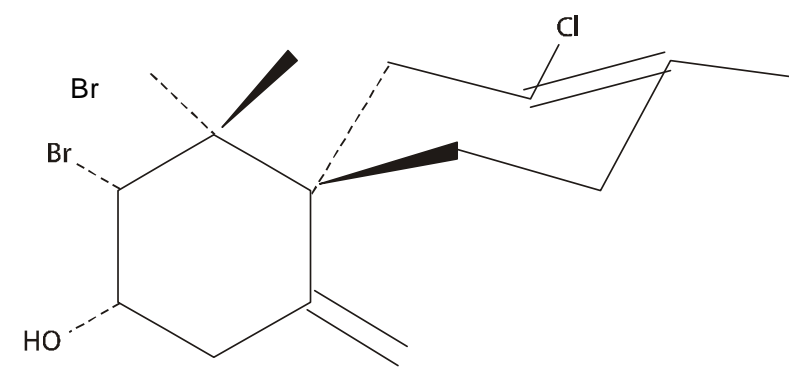

Fig. 1 - Elatol, the major secondary metabolite from Brazilian specimens of L. obtusa. 


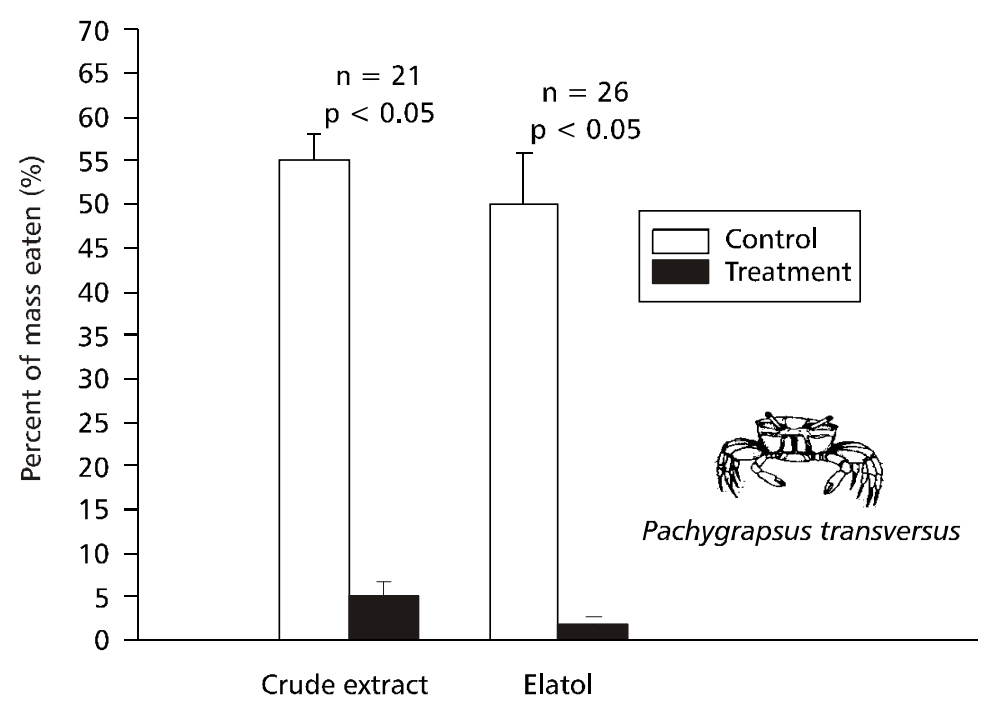

Fig. 2 - The effect of crude extract and elatol from L. obtusa on feeding by the crab P. transversus. Difference between means were considered significant when $\mathrm{p}<0.05$ (Wilcoxon matched pairs test). Vertical bars are standard deviations. $\mathrm{n}=$ number of replicates.

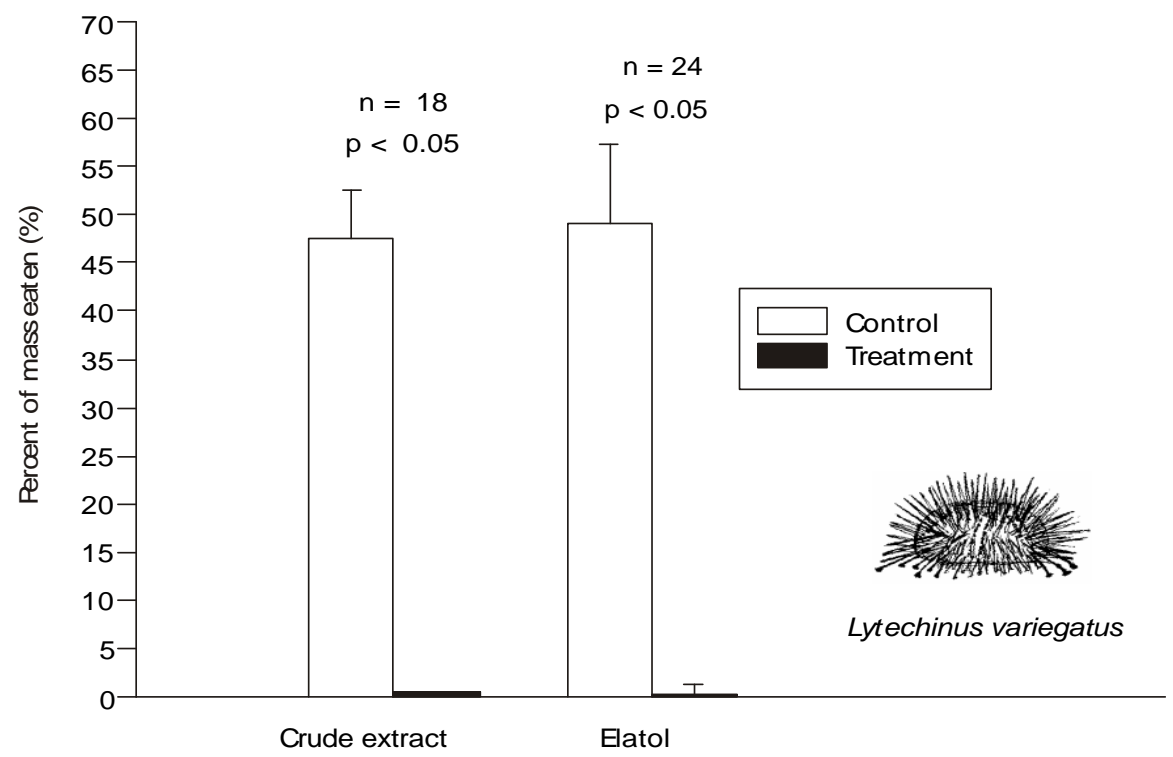

Fig. 3 - The effect of crude extract and elatol from L. obtusa on feeding by the sea urchin $L$. variegatus. Difference between means were considered significant when $\mathrm{p}<0.05$ (Wilcoxon matched pairs test). Vertical bars are standard deviations. $\mathrm{n}=$ number of replicates. 


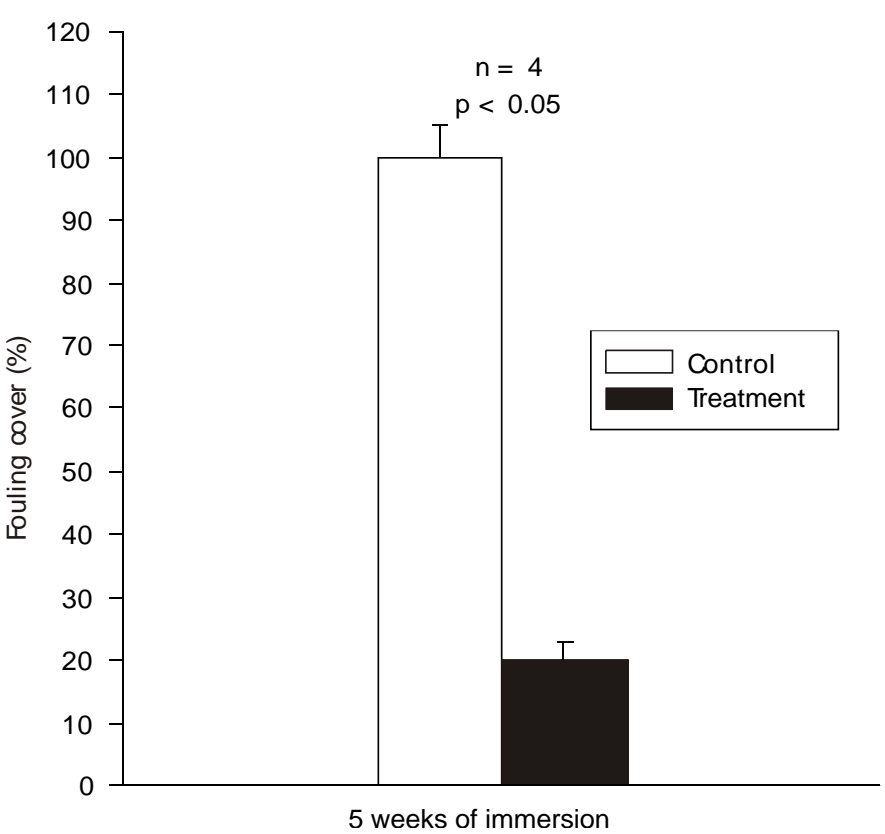

Fig. 4 - Total fouling cover (\%) on control gels and gels containing the crude extract of L. obtusa after 5 weeks of immersion in the sea. Results are presented as the mean of four replicates + one standard deviation, and were considered significant when $\mathrm{p}<0.05$ (one-way ANOVA followed by Tukey HSD test).

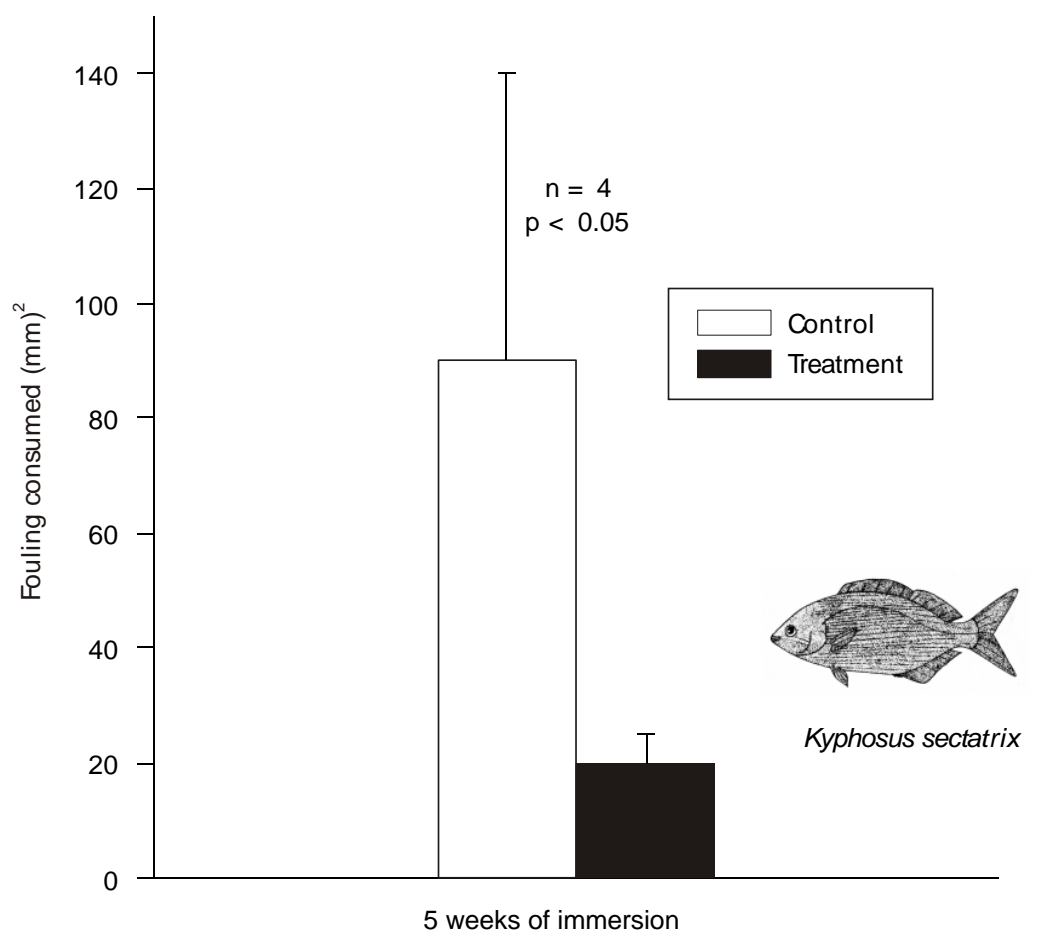

Fig. 5 - Fouling cover on gels $\left(\mathrm{mm}^{2}\right)$ consumed by predatory fish after 5 weeks of immersion in the sea. Results are expressed as the mean of four replicates + one standard deviation, and were considered significant when $\mathrm{p}<0.05$ (one-way ANOVA followed by Tukey HSD test). 
Besides the defensive properties against herbivores (Hay et al., 1987, 1988; Paul et al., 1988; present study), elatol is a cytotoxin, which at a concentration of $7 \mathrm{~g} . \mathrm{ml}^{-1}$ inhibits $50 \%$ of cell division in fertilized sea urchin eggs (Norris \& Fenical, 1982), and which is the major compound of L. obtusa crude extrac. This extract has proven broadly active as an antifoulant in both laboratory assays (da Gama et al., 2003) and the field (da Gama et al., 2002). Thus, elatol may be considered a rare example of a compound that exhibits strong biological activity in laboratory tests and also exhibits significant ecological importance in the field. In general, defensive chemicals against fishes and urchins do not affect small and relatively sedentary herbivores (= mesograzers) such as amphipods, polychaetes, and crabs. In fact, mesograzer herbivores subjected to high predation rates may preferentially feed on these types of plants in order to minimize their susceptibility to natural enemies (Duffy \& Hay, 1994). Here, it was verified that herbivory by both the mesograzer $P$. transversus and a large mobile herbivore, L. variegatus was inhibited by the sesquiterpene alcohol elatol. Considering that both of the above herbivores are sympatric, the chemically deterrent property of elatol very likely plays an ecologically relevant role against herbivores.

The negative effects in marine systems of fouling on host plants have been extensively documented and include light and nutrient availability decreases; flexibility loss resulting in increased brittleness; mechanical damage of host surfaces; changes of surface $\mathrm{pH}$; and changes in drag which can cause breakage during storms (Davis et al., 1989; Wahl, 1989; Williams \& Seed, 1992). Host plants can also be fouled by higher preference epibionts, thus suffering not only the direct negative effects of being fouled (Davis et al., 1989; Wahl, 1989; Williams \& Seed, 1992), but also experiencing increased grazing rates (Wahl \& Hay, 1995; Karez et al., 2000). All these processes could select for seaweed characteristics that minimize colonization by fouling organisms, i.e., the production of chemical defenses against epibiosis.

Our results suggest that an epibiont cover may act as a lure to predatory fish, i.e., epibionts may attract consumers that otherwise would not feed significantly on the host plant (Karez et al., 2000). Thus, the major compound elatol presumably plays a multiple-function role for Brazilian L. obtusa specimens, simultaneously preventing fouling organisms from settling (da Gama et al., 2002) and deterring diverse herbivores (Hay et al., 1987, 1988; Granado \& Caballero, 1995; and the present paper).

In this study, it was found that chemicals produced by L. obtusa from the Brazilian coast significantly reduce herbivory. It was also verified that the antifouling property of the chemicals produced by this species could make this red alga less attractive to fish grazing. In addition to the known multiple ecological functions carried out by Dictyotaceae natural products (e.g., Schmitt et al., 1995, 1998), the sesquiterpene elatol found in Brazilian L. obtusa and also in Laurencia species worldwide, may exhibit multiple functions in the marine environment, thereby increasing the adaptive value of this metabolite for several algae of the genus Laurencia.

Acknowledgments - CNPq and FAPERJ supported this research. B. A. P. G. gratefully acknowledges CAPES for providing his fellowship. R. C. P., V. L. T., and Y. Y. V. thank CNPq for Research Productivity Fellowships. C. E. L. Ferreira and J. E. A. Gonçalves (IEAPM) identified the fish species.

\section{REFERENCES}

DA GAMA, B. A. P., 2001, Papel multifuncional de produtos naturais da alga marinha Laurencia obtusa (Hudson) Lamouroux (Rhodophyta, Ceramiales). Tese de Doutorado, Universidade Federal do Rio de Janeiro.

DA GAMA, B. A. P., PEREIRA, R. C., CARVAlHO, A. G. V., COUTINHO, R. \& YONESHIGUE-VALENTIN, Y., 2002, The effects of seaweed secondary metabolites on biofouling. Biofouling, 18: 13-20.

DA GAMA, B. A. P., PEREIRA, R. C., SOARES, A. R., TEIXEIRA, V. L. \& YONESHIGUE-VALENTIN, Y., 2003, Is the mussel test a good indicator of antifouling activity? A comparison between laboratory and field assays. Biofouling, 19: 161-169.

DAVIS, A. R., TARGETT, N. M., MCCONNELL, O. J. \& YOUNG, C. M., 1989, Epibiosis of marine algae and benthic invertebrates: natural products chemistry and other mechanisms inhibiting settlement and overgrowth. In: P. J. Scheuer (ed.), Bioorganic marine chemistry. 3. vol. Springer-Verlag, Berlin, pp. 85-114.

DE NYS, R., DWORJANYN, S. A. \& STEINBERG, P. D., 1998, A new method for determining surface concentrations of marine natural products on seaweeds. Mar. Ecol. Prog. Ser., 162: 79-87.

DE NYS, R., LEYA, T., MAXIMILIEN, R., AFSAR, A., NAIR, P. S. R. \& STEINBERG, P. D., 1996, The need for standardised broad scale bioassay testing: a case study using the red alga Laurencia rigida. Biofouling, 10: 213-224.

DUFFY, J. E. \& HAY, M. E., 1994, Herbivore resistance to seaweed chemical defense: the roles of mobility and predation risk. Ecology, 75: 1304-1319.

FAULKNER, D. J., 2001, Marine natural products. Nat. Prod. Rep., 18: 1-49. 
FENICAL, W., 1975, Halogenation in the Rhodophyta: a review. J. Phycol., 11: 245-259.

FOSTER, M. S., HARROLD, C. \& HARDIN, D. D., 1991, Point versus photo quadrat estimates of the cover of sessile marine organisms. J. Exp. Mar. Biol. Ecol., 146: 193-203.

GRANADO, I. \& CABALLERO, P., 1995, Chemical defense in the seaweed Laurencia obtusa (Hudson) Lamouroux. Sci. Mar., 59: 31-39.

HAY, M. E., FENICAL, W. \& GUSTAFSON, K., 1987, Chemica defense against diverse coral reef herbivores. Ecology, 68: 1581-1591.

HAY, M. E., KAPPEL, Q. E. \& FENICAL, W., 1994, Synergisms in plant defenses against herbivores: interactions of chemistry, calcification, and plant quality. Ecology, 75: 1714-1726.

HAY, M. E. \& STEINBERG, P. D., 1992, The chemical ecology of plant-herbivore interactions in marine versus terrestrial communities. In: J. Rosenthal \& M. Berenbaum (eds.), Herbivores: their interaction with secondary plant metabolites. Evolutionary and ecological processes, vol. II. Academic Press, New York, pp. 371-413.

HENRIKSON, A. A. \& PAWLIK, J. R., 1995, A new antifouling assay method: results from field experiments using extracts of four marine organisms. J. Exp. Mar. Biol. Ecol., 194: 157165.

KAREZ, R., ENGELBERT, S. \& SOMMER, U., 2000, 'Coconsumption' and 'protective coating': two new proposed effects of epiphytes on their macroalgal hosts in mesograzer-epiphytehost interactions. Mar. Ecol. Prog. Ser., 205: 85-93.

KÖNIG, G. M., WRIGHT, A. D. \& FRANZBLAU, S. G., 2000, Assessment of antimycobacterial activity of a series of mainly marine derived natural products. Planta Med., 66: 337-342.

KÖNIG, G. M. \& WRIGHT, A. D., 1997, Laurencia rigida: chemical investigations of its antifouling dichloromethane extract. J. Nat. Prod., 60: 967-970.

McClinTOCK, J. B. \& BAKER, B. J. (eds.), 2001, Marine chemical ecology. CRC Press.

MUNRO, M. H. G. \& BLUNT, J. W., 1999, Marinlit, version 10.4, Marine Chemical Group, University of Canterbury, Christchurch, New Zealand.

NORRIS, J. N. \& FENICAL, W., 1982, Chemical defense in tropica marine algae. In: K. Rutzler \& I. G. Macintyre (eds.), Atlantic barrier reef ecosystem, Carrie Bow Cay, Belize. I. Structure and Communities. Smith. Contr. Mar. Sci., 12: 417-431.

OLIVEIRA FILHO, E. C., 1977, Algas marinhas bentônicas do Brasil. Livre Docência Thesis, Universidade de São Paulo.

PAUL, V. J., 1992, Ecological roles of marine natural products. Comstock, Ithaca, New York, USA.

PAUL, V. J. \& FENICAL, W., 1986, Chemical defense in tropical green algae, order Caulerpales. Mar. Ecol. Prog. Ser., 34: 157-169.

PAUL, V. J. \& FENICAL, W., 1987, Natural products chemistry and chemical defense in tropical marine algae of the phylum Chlorophyta. In: P. J. Scheuer (ed.), Bioorganic marine chemistry, 1. vol. Springer-Verlag, pp. 1-37.

PAUL, V. J., WYLIE, C. R. \& SANGER, H. R., 1988, Effects of algal chemical defenses toward different coral-reef herbivorous fishes. Proc. $6^{\text {th }}$ Coral Reef Symp., 3: 73-78.
PAUL, V. J. \& VAN ALSTYNE, K. L., 1988, Chemical defense and chemical variation in some tropical Pacific species of Halimeda (Chlorophyta, Halimedaceae). Coral Reefs, 6: 263270.

PEREIRA, R. C., 1995, O uso de sesquiterpenos na taxonomia e biogeografia de espécies do gênero Laurencia Lamouroux. Tese de Doutorado, Universidade Federal do Rio de Janeiro, Núcleo de Pesquisas de Produtos Naturais, 184p.

PEREIRA, R. C., CAVALCANTI, D. N. \& TEIXEIRA, V. L., 2000, Effects of secondary metabolites from the tropical Brazilian brown alga Dictyota menstrualis on the amphipod Parhyale hawaiensis. Mar. Ecol. Prog. Ser., 60: 405-414.

PEREIRA, R. C., PINHEIRO, M. D. \& DA GAMA, B. A. P., 2002, Feeding preference of the endemic gastropod Astraea latispina in relation to chemical defenses of Brazilian tropical seaweeds. Braz. J. Biol. 62: 33-40.

PEREIRA, R. C., TEIXEIRA, V. L. \& KELECOM, A., 1994, Chemical defenses against herbivores in marine algae. 1. The brown alga Dictyota dichotoma (Hudson) Lamouroux from Brazil. Rev. Bras. Biol., 66: 230-235.

PEREIRA, R. C. \& TEIXEIRA, V. L., 1999, Sesquiterpenos da alga marinha Laurencia Lamouroux (Ceramiales, Rhodophyta). 1. Significado ecológico. Química Nova, 22: 369-373.

PEREIRA, R. C. \& YONESHIGUE-VALENTIN, Y., 1999, The role of polyphenols from the tropical brown alga Sargassum furcatum on the feeding by amphipod herbivores. Bot. Mar., 42: 441-448.

RAGAN, M. A. \& GLOMBITZA, K. W., 1986, Phlorotannins: brown algal polyphenols. Prog. Phycol. Res., 4: 130-241.

SCHMITT, T. M., HAY, M. E. \& LINDQUIST, N., 1995, Constraints on chemically mediated coevolution: multiple functions for seaweed secondary metabolites. Ecology, 76: 107-123.

SCHMITT, T. M., LINDQUIST, N. \& HAY, M. E., 1998, Seaweed secondary metabolites as antifoulants: effects of Dictyota spp. diterpenes on survivorship, settlement, and development of marine invertebrate larvae. Chemoecology, 8: 125-131.

SIMS, J. J., LIN, G H. Y. \& WING, R. M., 1974, Elatol, a halogenated sesquiterpene alcohol from the red alga Laurencia elata. Tetrahedron Lett., pp. 3487-3490.

TARGETT, N. M. \& ARNOLD, T. M., 2001, Effect of secondary metabolites on digestion in marine herbivores. In: J. B. McClintock \& B. B. J. Baker (eds.), Marine chemical ecology. CRC Press, pp. 391-411.

WAHL, M., 1989, Marine epibiosis. I. Fouling and antifouling: some basic aspects. Mar. Ecol. Prog. Ser., 58: 175-189.

WAHL, M. \& HAY, M. E., 1995, Associational resistance and shared doom: effects of epibiosis on herbivory. Oecologia, 102: 329-340

WILLIAMS, G. A. \& SEED, R., 1992, Interactions between macrofaunal epiphytes and their host algae. In: D. M. John, S. J. Hawkins \& J. H. Price (eds.), Plant-animal interactions in the marine benthos. (Systematics Association, special vol. 46) Clarendon Press, Oxford, pp. 189-211. 